\title{
Africa's highest mountain harbours Africa's tallest trees
}

\author{
Andreas Hemp ${ }^{1,2}$ (D) Reiner Zimmermann ${ }^{3}$ - Sabine Remmele ${ }^{3}$. \\ Ulf Pommer ${ }^{2} \cdot$ Bernd Berauer $^{3}$ - Claudia Hemp ${ }^{4}$. \\ Markus Fischer ${ }^{2,5,6}$
}

Received: 2 August 2016/Revised: 7 September 2016/Accepted: 24 September 2016/ Published online: 17 October 2016

(C) The Author(s) 2016. This article is published with open access at Springerlink.com

\begin{abstract}
While world records of tree heights were set by American, Australian and Asian tree species, Africa seemed to play no role here. In our study we show that Entandrophragma excelsum (Meliaceae) found in a remote valley at Kilimanjaro has to be included in the list of the world's superlative trees. Estimating tree age from growth rates monitored by high resolution dendrometry indicates that tall individuals may reach more than 470 years of age. A unique combination of anatomical peculiarities and favorable site conditions might explain their enormous size. The late date
\end{abstract}

Communicated by Peter Ashton.

This article belongs to the Topical Collection: Forest and plantation biodiversity.

Andreas Hemp

andreas.hemp@uni-bayreuth.de

Reiner Zimmermann

rzimmerm@uni-hohenheim.de

Sabine Remmele

sabine.remmele@uni-hohenheim.de

Ulf Pommer

upommer@aol.com

Bernd Berauer

bernd.berauer@uni-bayreuth.de

Claudia Hemp

claudia.hemp@uni-wuerzburg.de

Markus Fischer

markus.fischer@ips.unibe.ch

1 Department of Plant Systematics, University of Bayreuth, 95440 Bayreuth, Germany

2 Senckenberg Gesellschaft für Naturforschung, Biodiversity and Climate Research Centre (BiK-F), 60325 Frankfurt, Germany

3 Institute of Botany (210), University of Hohenheim, 70593 Stuttgart, Germany 
of this discovery of Africa's tallest trees may be due to the comparably low study efforts at Kilimanjaro compared with other biodiversity hotspots. Since only a few square kilometers of this habitat of Entandrophragma are left, Kilimanjaro (and Africa) is about to lose not only a unique biogeographical archive with highly diverse vegetation, but also its tallest trees. The inclusion of these valleys into the immediately neighboring Kilimanjaro National Park would be an excellent and urgent possibility of protection.

Keywords Biodiversity · East Africa - Entandrophragma excelsum - Global change · Tree growth - Tropical submontane and lower montane forest

\section{Introduction}

Trees grow tall where resources are abundant, stresses are minor, and competition for light forces priority on height growth (King 1991). Tall trees were reported from North America with the tallest known tree on Earth (giant redwood, Sequoia sempervirens, $112.7 \mathrm{~m}$ ), from Australia (mountain ash, Eucalyptus regnans, $99.6 \mathrm{~m}$ ) or Borneo (yellow meranti, Shorea faguetiana, $89.5 \mathrm{~m}$ ) (Tng et al. 2012; Klein 2016). Tree reports from Africa so far suggest that trees grow not taller than 65 m (FTEA 1952-2012). The only exception is an individual of an introduced species, Sydney blue gum (Eucalyptus saligna), which grew $81.5 \mathrm{~m}$ tall prior to its death in 2006 (http://git-forestry-blog. blogspot.com/2008/07/tallest-tree-in-africa-is-you-guessed.html). However, many areas of Africa are understudied, especially outside the biodiversity hotspots, such as the Cape region or the Eastern Arc Mountains. Thus, tall tree species may have been overlooked. Moreover, many tree species may have been recorded in habitats where limited resource abundance, high competition, or low priority of height have prevented very tall growth.

Africa's highest mountain offers a huge variety of forest types ranging from dry succulent forests on the foothills to luxuriant lower to upper montane rainforests (Hemp 2006a, b). As one of the most famous mountains of the world, the flora and vegetation of Kilimanjaro are considered to be well investigated. Over the last 25 years we studied the vegetation of Kilimanjaro in almost 1700 plots distributed all over the mountain. This included some 600 forest plots, including several research plots recently established in submontane forests at $1600 \mathrm{~m}$ elevation. In this area environmental conditions are very favorable and therefore most of it is used for traditional agroforestry, coffee plantations, or as grasslands. Remains of lower montane forests are very limited and are typically found in and close to steep gorges, which makes land use difficult. These small forest relicts of a few square kilometers suggest that a rich forest flora once inhabited Mt. Kilimanjaro, with undescribed and restricted-range species otherwise only known from the Eastern Arc Mountains, a chain of ancient mountains and a hotspot of biodiversity in East Africa

\footnotetext{
4 Department of Animal Ecology and Tropical Biology, Biocenter, University of Würzburg, Am Hubland, 97074 Würzburg, Germany

5 Institute of Plant Sciences, University of Bern, Altenbergrain 21, 3013 Bern, Switzerland

6 Oeschger Centre for Climate Change Research, Zähringerstrasse 24, 3012 Bern, Switzerland
} 
(Hemp 2006a). Recently we recorded extraordinary tall specimens of Entandrophragma excelsum (Dawe and Sprague) Sprague (Meliaceae) in these gorges. Having confirmed the existence of these forest giants, we asked three questions: (1) why is this species so tallwhich general mechanisms for survival and old age are found for "giant" tree species, (2) how is E. excelsum ranked within the list of superlative trees on the African continent and the world and (3) how is its conservation status.

\section{Materials and methods}

We established over 1700 vegetation plots (including over 600 forest plots) following the Method of Braun-Blanquet (1964) all over Kilimanjaro during the last 20 years, from where we took the maximum tree heights of the discussed trees. Within the frame of the DFG funded research unit FOR 1246 we added 65 permanent research plots for long-term monitoring and experiments distributed along 5 transects ranging from 860 to $4550 \mathrm{~m}$ on the southern slope of Kilimanjaro, where we did forest inventories.

Tree wood density was determined from tree cores $(50 \mathrm{~cm}$ length, diameter $5.15 \mathrm{~mm}$, taken in February 2015). Tree cores were cut in $1 \mathrm{~cm}$ radial xylem steps from cambium to pith depth and dried $72 \mathrm{~h}$ at $103{ }^{\circ} \mathrm{C}$ according to Williamson and Wiemann (2010).

Tree height $(\mathrm{H})$, diameter of the main stem near ground height (DGH), i.e. not considering the much wider buttress roots, of 32 individuals of Entandrophragma excelsum and the stem shape dimensions for a subset of twenty individuals (including exact dimensions of the often large buttress roots) were measured using a Laser dendro-relascope (Criterion, Laser Tech Inc., USA) from March 2012 until March 2016. For all individuals the main stem and all main branch dimensions were measured optically with a Relascope with magnification optics set up on a tripod (Criterion, Laser Tech Inc., USA) and a Laser Rangefinder (TRU Pulse 200, Laser Tech Inc., USA).

Stem and branch volumes were calculated using sequential cylindrical cone volumes and measured wood densities of stem wood and buttress roots. For bark biomass, bark depth was determined for all trees and a linear bark depth decrease with tree height assumed.

The temporal dynamics of cambial cell growth at three stems of E. excelsum were monitored $2 \mathrm{~m}$ above the ground, where the permanent radial stem extension was measured with high resolution point dendrometers $(0.01 \mathrm{~mm}$ resolution, Megatron MM10 11 R1K, Munich, Germany) from March 2012 until March 2016. Seasonal growth dynamics were verified with micro-core samples obtained with a Trephor probe (Rossi et al. 2006) from the same individuals measured with point dendrometers every two months.

Nomenclature follows FTEA (1952-2012).

\section{Results}

The ten tallest individuals of Entandrophragma excelsum ranged from 59.2 to $81.5 \mathrm{~m}$ and 1.24 to $2.55 \mathrm{~m}$ diameter. Table 1 shows the dimensions of the thirteen tallest measured individuals, all exceeding $50 \mathrm{~m}$ in height. In the lists of the world's tallest tree species with heights of $80 \mathrm{~m}$ and more no African species are mentioned (Tng et al. 2012). Most of the tallest indigenous trees in tropical Africa (with heights of 50-60 m including several 
Table 1 Biometric dimensions of Entandrophragma excelsum

\begin{tabular}{lllll}
\hline Number & DGH $(\mathrm{cm})$ & Height $(\mathrm{m})$ & AGWB $(\mathrm{Mg})$ & Crown volume $\left(\mathrm{m}^{3}\right)$ \\
\hline 1 & 255.0 & 81.5 & n.m. & n.m. \\
2 & 164.0 & 74.2 & 80.4 & 11,666 \\
3 & 160.0 & 67.7 & 60.3 & 7642 \\
4 & 154.0 & 64.0 & 54.2 & 4035 \\
5 & 178.0 & 63.5 & 58.6 & n.m. \\
6 & 180.0 & 62.4 & n.m. & n.m. \\
7 & 98.2 & 62.3 & n.m. & n.m. \\
8 & 117.0 & 60.6 & n.m. & n.m. \\
9 & 187.0 & 59.8 & 77.4 & 3763 \\
10 & 124.0 & 59.2 & 68.4 & 11,271 \\
11 & 110.0 & 57.4 & 14.1 & 4694 \\
12 & 126.0 & 55.7 & 36.1 & 11,352 \\
13 & 62.9 & 53.7 & 4.9 & 1499 \\
\hline
\end{tabular}

$D G H$ diameter of main stem near ground, height, $A G W B$ above ground woody biomass and crown volume of the 13 tallest individuals found at Kilimanjaro, n.m. not measured

species of Entandrophragma) occur in the West African lowland rainforests [about 30 species (FTEA 1952-2012; FWTA 2014)]. Once there was a tall Sydney blue gum (Eucalyptus saligna) with $81.5 \mathrm{~m}$ height at Woodbush Forest Reserve, South Africa. However, this tree was a planted non-indigenous species, which fell down in 2006 (http://git-forestryblog.blogspot.com/2008/07/tallest-tree-in-africa-is-you-guessed.html). On Kilimanjaro the tallest tree species on our 600 forest plots-besides Entandrophragma-are Camphor (Ocotea usambarensis, Lauraceae) with $40 \mathrm{~m}$, Muna tree (Aningeria adolfi-friederici, Sapotaceae) with $45 \mathrm{~m}$, Forest Newtonia (Newtonia buchananii, Mimosaceae) with $45 \mathrm{~m}$, Garcinia tanzaniensis (Clusiaceae) with $47 \mathrm{~m}$, Strombosia (Strombosia scheffleri, Olacaceae) with $47 \mathrm{~m}$ and African juniper (Juniperus procera, Juniperaceae) with $45 \mathrm{~m}$. With specimens of over $81 \mathrm{~m}$ and 80 tons of woody biomass Entandrophragma excelsum growing at Kilimanjaro has to be included in the hit list of world's superlative trees (Fig. 1).

Entandrophragma excelsum occurs in east and eastern central Africa in (sub)montane rain forests between (925) 1280-2150 m. It is native to the Congo, Malawi, Tanzania, Uganda, Zambia and its highest recorded heights are 55 m (FTEA 1952-2012).

On Kilimanjaro it grows between 1400 and $2100 \mathrm{~m}$, an elevational range, which belongs following the delineation of East African forest zones of Hemp (2006a) to the submontane and lower montane forest zone, following the universal delineation of Grubb (1977) and Whitmore (1991) to the tropical lower montane forest zone. Entandrophragma is mainly restricted (beside few occurrences in lower montane Cassipourea forests of the northern slope) to Newtonia ravine forest relicts found in the submontane cultivated zone of the southern slope (Hemp 2006a, b). Here it grows on the steep $\left(30^{\circ}-40^{\circ}\right)$ lower slopes and forms, with few other tree species, the upper canopy typically reaching 50-60 m. With its spreading large branches (Figs. 2, 3), Entandrophragma has the function as the most important epiphyte host tree of submontane forests at Kilimanjaro. Its upper branches are densely covered by ferns such as Basket fern (Drynaria volkensii) and other 50 on this tree recorded epiphyte species (Figs. 2, 3). E. excelsum does not occur in dense stands but is a 


$\begin{array}{lcccccc} & \begin{array}{c}\text { Sequoia } \\ \text { sempervirens }\end{array} & \begin{array}{c}\text { Sequoiadendron } \\ \text { giganteum }\end{array} & \begin{array}{c}\text { Eucalyptus } \\ \text { regnans }\end{array} & \begin{array}{c}\text { Eucalyptus } \\ \text { viminalis }\end{array} & \begin{array}{c}\text { Petersianthus } \\ \text { quadrialatus }\end{array} & \begin{array}{c}\text { Entandrophragma } \\ \text { excelsum }\end{array} \\ \text { Height: } & 115.7 \mathrm{~m} & 94.9 \mathrm{~m} & 99.8 \mathrm{~m} & 89.0 \mathrm{~m} & 87.8 \mathrm{~m} & 81.5 \mathrm{~m} \\ \text { Girth: } & 28.2 \mathrm{~m} & 27.8 \mathrm{~m} & 12.73 \mathrm{~m} & 11.0 \mathrm{~m} & \approx 11.5 \mathrm{~m} & 8.0 \mathrm{~m}\end{array}$
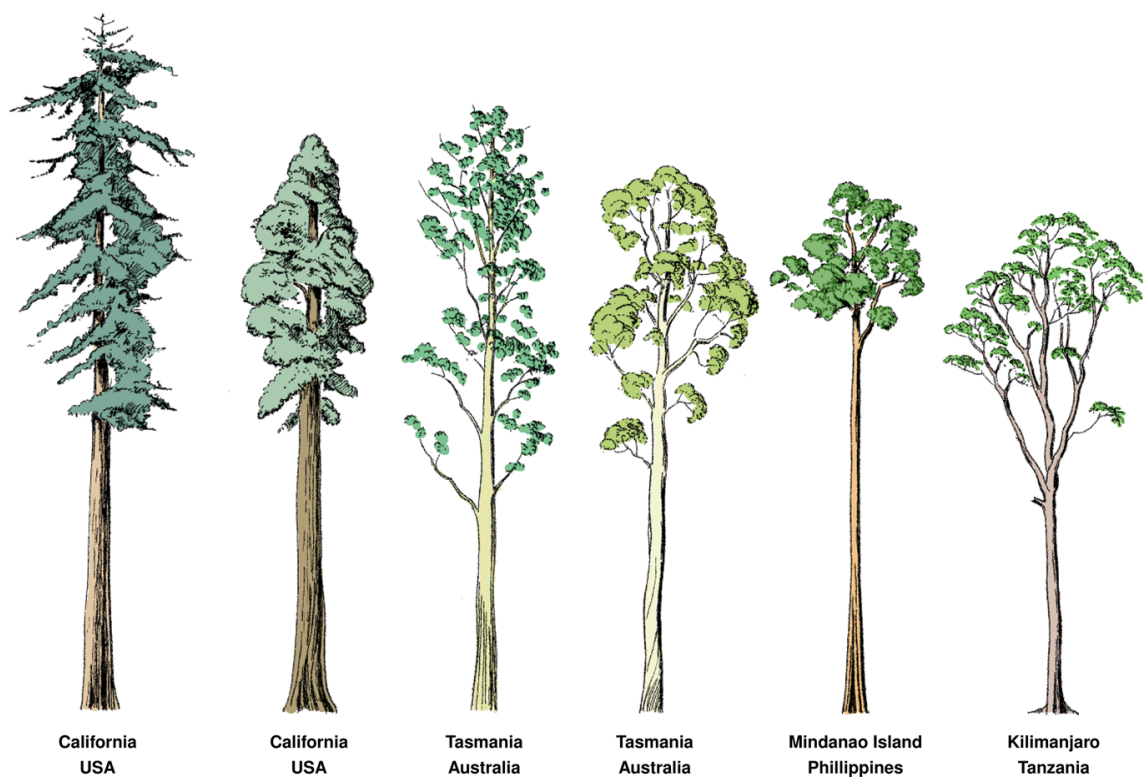

Fig. 1 The height, girth, and locations of some of the world's tallest tree species

rare constituent of the upper tree canopy. Based on two $50 \times 50 \mathrm{~m}$ permanent submontane Newtonia forest plots (Fig. 4), where we did forest inventories we calculated a number of 16 tall $(>50 \mathrm{~m})$ specimens of Entandrophragma per ha of undisturbed forest. This may exactly reflect the conditions for tall tree growth: a gorge situation with tall trees calling for especially high height growth, and otherwise good conditions, and little competition between the tallest species.

The submontane zone (lower montane zone in the sense of Grubb (1977) and Whitmore (1991)) of Kilimanjaro's southern slope displays a favorable climate with high precipitation and warm temperature in combination with a high fertility of the volcanic soils. The climate of the submontane Newtonia forests is perhumid, with a mean annual temperature of $17.5^{\circ} \mathrm{C}$ and mean annual precipitation exceeding $1800 \mathrm{~mm}$ (Hemp 2006a, b). Global analyses have shown that precipitation is a poor predictor of tree height (King 1991) or biomass (Keith et al. 2009) when forest landscapes are compared. Instead, temperature distribution seems to be the most significant determinant of tall tree growth, supporting the energetic and biomechanical approach to understanding tree size and allometry (Larjavaara 2014). The tallest trees grow in climates with small seasonal temperature variation (Larjavaara 2014). The $17.5 \%$ mean annual temperature and the $5{ }^{\circ} \mathrm{C}$ variation at Kilimanjaro are within these climatic conditions. However, according to Whitmore (1991) emergent trees of heights of 60 up to $80 \mathrm{~m}$ are characteristic to tropical lowland evergreen forests but not for tropical lower montane rain forests, although Ashton (2014) reports trees of exceptional stature (albeit not precisely measured) at similar elevation and habitat on the slopes of Thailand's highest mountain. 


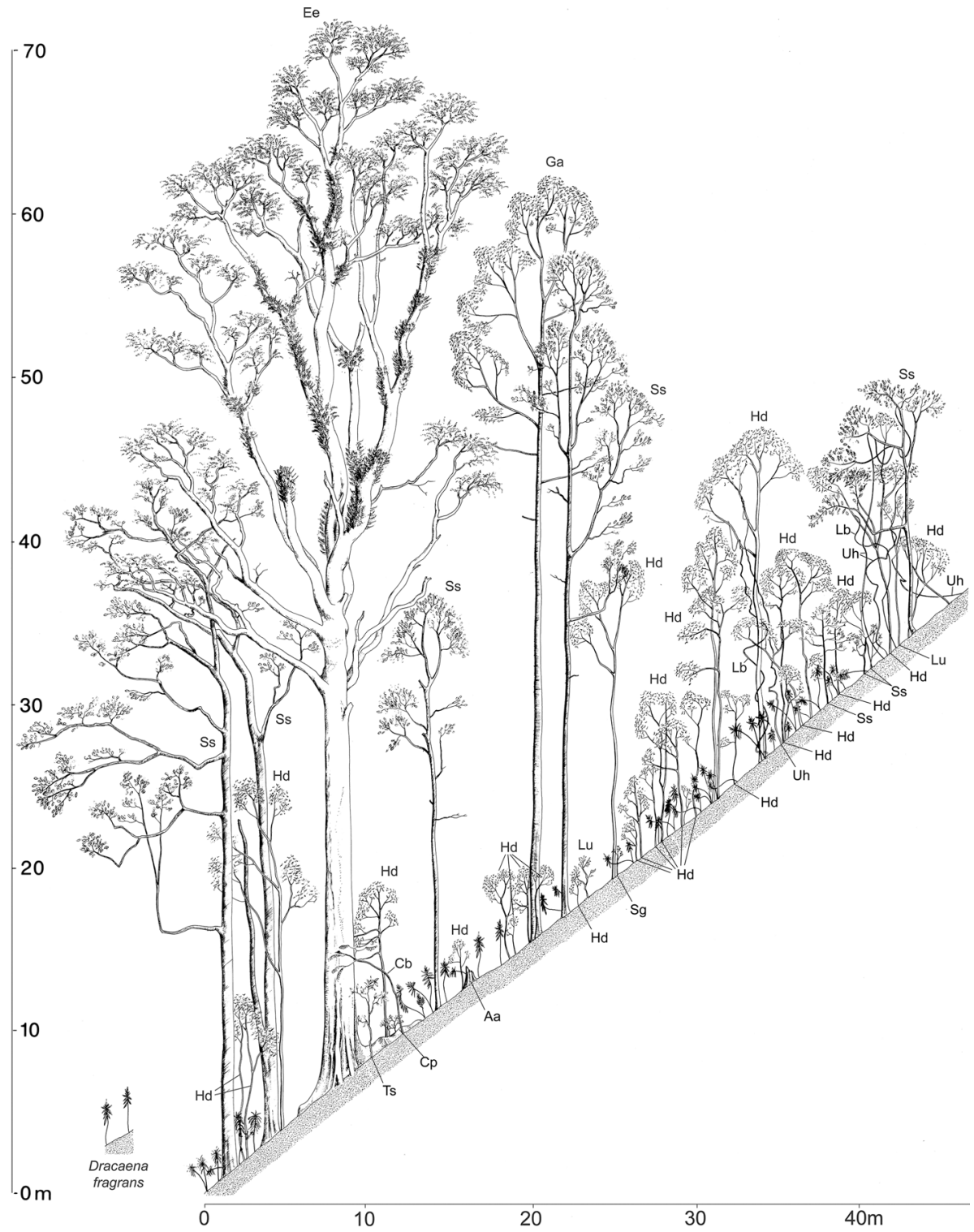

Fig. 2 Profile $(45 \times 5 \mathrm{~m})$ of a submontane forest at $1620 \mathrm{~m}$ a.s.l. on the southern slope of Kilimanjaro. Aa: Aningeria adolf-friederici (death), Cb: Casearia battiscombei, Cp: Chassalia parvifolia, Ee: Entandrophragma excelsum (in Fig. 3 in Hemp 2006a, b erroneous labelled as Eckebergia capensis), Ga: Garcinia tanzaniensis, Hd: Heinsenia diervilleoides, Lb: Landolphia buchananii, Lu: Leptonychia usambarensis, Sg: Syzygium guineense, Ss: Strombosia scheffleri, Uh: Urera hypselodendron. Mean canopy height $40 \mathrm{~m}$ with some emergent trees (Entandrophragma excelsum) reaching heights of over $60 \mathrm{~m}$ and densely covered by epiphytes (Drynaria volkensii). In the upper part of the profile lianas and shrubs form dense thickets under a gap in the tree canopy

Trees in fertile soils build a lot of leaf mass and grow faster (Valentine and Makela 2012). The soils of the submontane Newtonia forests are deep humic ferrisols with dark brown humus-rich loamy topsoils and a moderately acid pH of 6.4 (Hemp 2006b; 


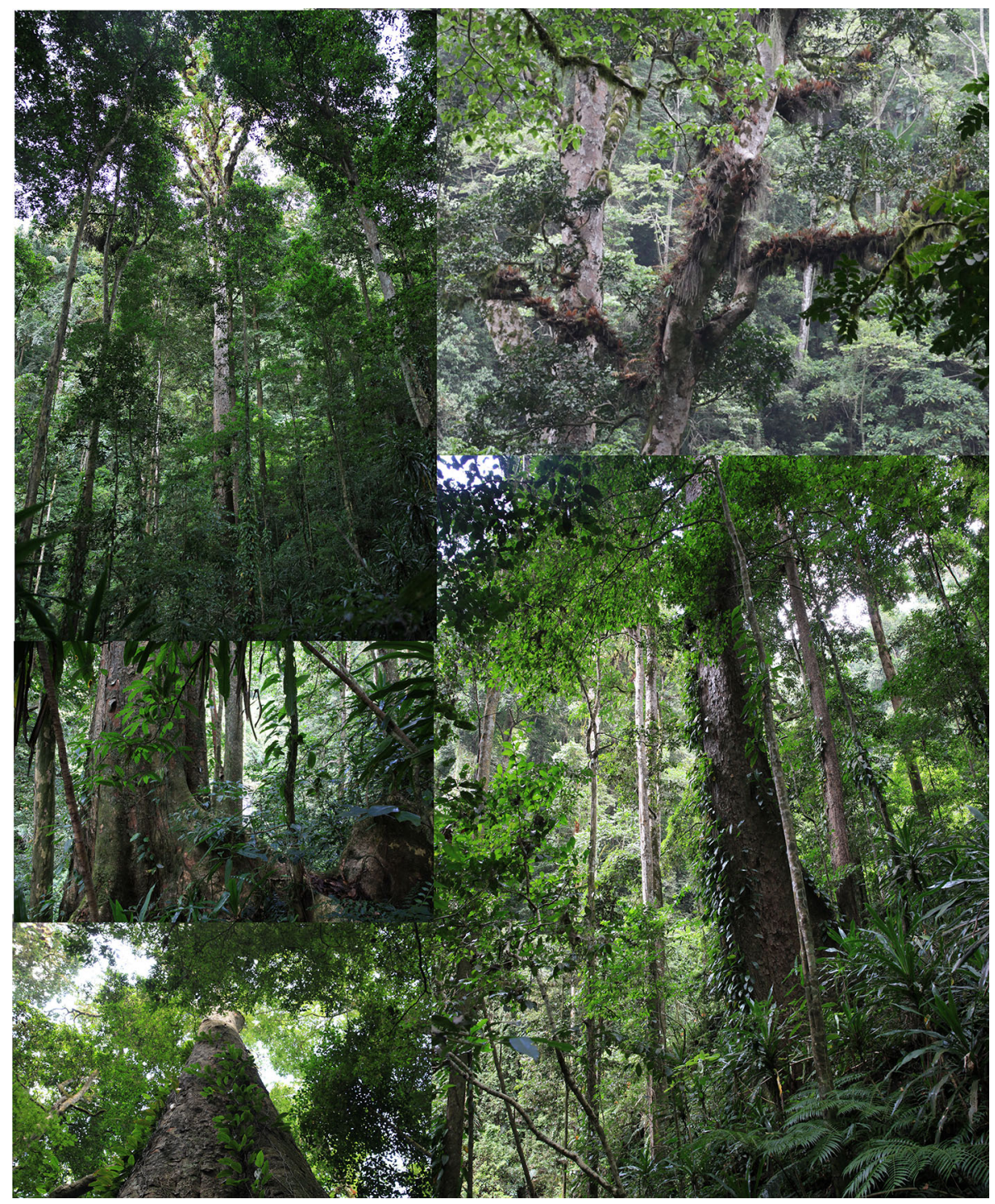

Fig. 3 Habitat of Entandrophragma excelsum at Kilimanjaro with forest undergrowth (mainly Dracaena fragrans, upper left and lower right), epiphytes (mainly Drynaria volkensii, upper right), buttresses (middle left) and low lianas (Culcasia falcifolia, lower left and right)

Anderson 1982). Under these conditions trees reach their maximum height and biomass at Kilimanjaro (Rutten et al. 2015; Ensslin et al. 2015). However, the Chagga people, inhabiting the lower slopes of Kilimanjaro since approximately 2000 years (Odner 1971) converted most of the former forests of this belt into agroforests.

Stem wood density of E. excelsum was on average $0.46 \mathrm{~g} \mathrm{~cm}^{-3}$ and varied between trees from 0.42 to $0.50 \mathrm{~g} \mathrm{~cm}^{-3}$. On average for mature E. excelsum trees, $4.3 \%$ of total stem and branch volume were bark. Of the twenty trees selected and measured for biomass estimation, the largest total above ground coarse woody biomass (stem, buttress roots and 


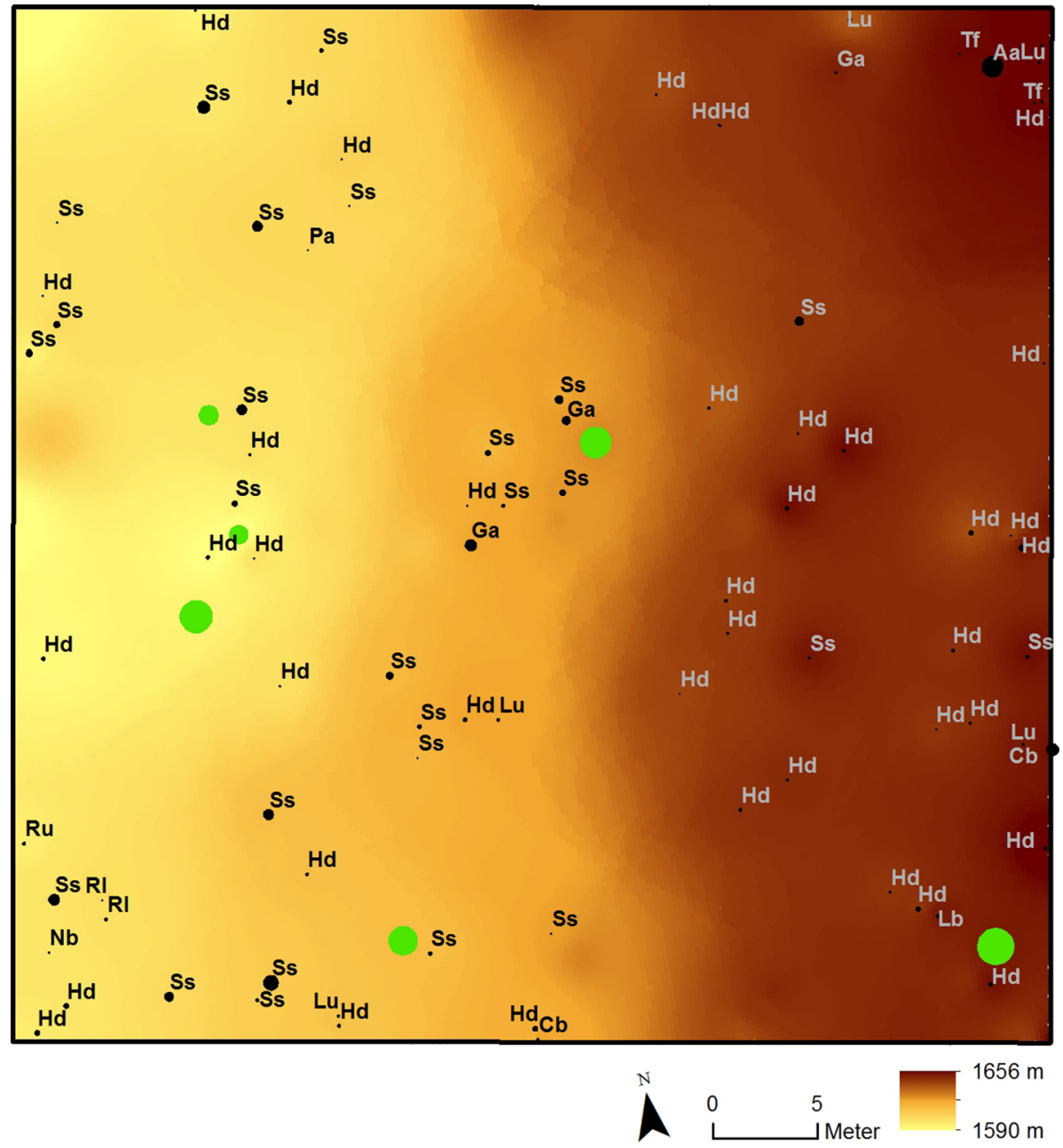

Fig. $450 \times 50 \mathrm{~m}$ map of a submontane forest at $1620 \mathrm{~m}$ a.s.l. on the southern slope of Kilimanjaro. Abbreviations of tree species as in Fig. 1; green circles Entandrophragma excelsum. Size of circles corresponds to tree diameter (DGH). Basal area was $62 \mathrm{~m}^{2} / \mathrm{ha}$

main branches combined) was $80.4 \mathrm{Mg}$ for the $74.2 \mathrm{~m}$ tall individual. This tree also had the biggest crown volume estimated to $11,666 \mathrm{~m}^{3}$ with an unusually large crown which contributed $64.0 \mathrm{Mg}$ to the total above ground woody biomass (AGWB). The stem weighted $15.1 \mathrm{Mg}$ and the buttress roots contributed $1.3 \mathrm{Mg}$.

Cambial cell enlargement in the main stem occurred almost exclusively during the main rainy season from March to June. The annual radial stem increment of the three observed trees ranged from 0.7 to $2.1 \mathrm{~mm}$. Annual increments were very consistent for each individual during the four years observed. E. excelsum at our site did not form specific anatomical ring features every year and did therefore not permit application of classic tree ring studies. We estimated tree age of E. excelsum using the observed actual annual maximum radial growth rate of $2.1 \mathrm{~mm}$ annually. Given the DGH values of 63 to $255 \mathrm{~cm}$ this indicates that tall individuals may reach at least between 150 to more than 607 years of 
age. Being conservative in estimate and taking into account that juvenile growth may be faster and assuming $5 \mathrm{~mm}$ /year for the first hundred years of growth, estimated maximum age would be still more than 470 years for the largest individual.

\section{Discussion}

While current thinking holds that tropical tall and long lived climax species tend to have high density wood, it was also argued (Larjavaara and Muller-Landau 2010) that low wood density actually offers higher strength at lower biological construction costs. Such tree species risk, however, low trunk safety margins against breakage in a gale and typically show poor survival in droughts. The wood density of E. excelsum at Kilimanjaro is in the lower range of the average specific wood density reported from other species of the genus such as Sipo Mahogany (E. utile) $0.53 \mathrm{~g} \mathrm{~cm}^{-3}$, African Mahogany (E. angolense) $0.45 \mathrm{~g} \mathrm{~cm}^{-3}$, Cedar Kokoti (E. candollei) $0.59 \mathrm{~g} \mathrm{~cm}^{-3}$ and Sapele (E. cylindricum) $0.55 \mathrm{~g} \mathrm{~cm}^{-3}$ (Reyes et al. 1992). Compared with most tropical tree species, these specific wood densities are moderate to low. Other tall trees of the same area, e.g. Newtonia, Strombosia and Aningeria had higher wood densities of up to $0.75 \mathrm{~g} \mathrm{~cm}^{-3}$ or more (Wheeler 2011). For the trees found in the deep, sheltered valleys at Kilimanjaro, neither strong winds nor drought appear to affect trees, important preconditions for tall tree growth (Koch et al. 2004). With its light wood E. excelsum is able to grow faster than other young late successional tree species with denser wood. Lowland tropical forest's tallest tree, Shorea faguetiana, is also a medium hardwood (generally $0.48-0.64 \mathrm{~g} \mathrm{~cm}^{-3}$, Newman et al. 1999). Thus E. excelsum successfully competes for light and escapes infestation by lianas until it reaches a certain "safe" stratum, i.e. the second tree layer of $40 \mathrm{~m}$. Due to the sheltered conditions and its light wood E. excelsum appears further able to even overtop this tree layer and to outcompete other tall trees. This might explain that we did not see even one specimen of Entandrophragma affected by large lianas as it was the case for other tall trees such as Newtonia and Aningeria. Only lianas reaching low heights of 10-20 m, such as Culcasia falcifolia, grew on its stems. (Figs. 2, 3). Only in the deepest valleys forest relicts survived at the lower slopes of Kilimanjaro. This may explain why they escaped earlier attention by botanists. This allowed us recently to discover a $40 \mathrm{~m}$ high tree species new to science in these gorges, now described as Garcinia tanzaniensis (Verdcourt 2007), a new epilithic fern species, now described as Lellingeria paucipinnata (Parris 2002) and several species not known from Tanzania before, e.g. Adiantum reniforme, which occurs in Africa only at 5 localities (Hemp 2002; Verdcourt 2002). In contrast to Kilimanjaro, which was not in the focus of naturalists, the Eastern Arc Mountains in its vicinity, a well-known hotspot of biodiversity, attracted much more attention. Consequently, quite a number of species so far considered endemics of the Eastern Arc turned out to occur also in the submontane forest relicts on Kilimanjaro (Hemp 2006b).

The number of large old trees in tropical forests is rapidly declining with serious implications for ecosystem integrity and biodiversity (Laurance et al. 2000; Lindenmayer et al. 2012, 2014; Lindenmayer and Laurance 2016). According to the IUCN red list $E$. excelsum is not endangered (least concern) (World Conservation Monitoring Centre 1998). Unlike the other members of the genus, which are commercial sources of African mahogany, this species is too rare to be exploited as a major commercial source of timber 
(World Conservation Monitoring Centre 1998). Furthermore its comparatively light wood tends to warp and to twist if used fresh (FTEA 1952-2012).

However, habitat loss is a more serious threat (World Conservation Monitoring Centre 1998). Submontane Newtonia forest relicts with 80-100 vascular plant species per 0.1 ha suggest a rich forest flora inhabited Kilimanjaro in former times, with undescribed or restricted-range species. The-compared with the Eastern Arc Mountains-observed low degree of endemism on Kilimanjaro may therefore result from the destruction of lower altitude forest rather than from the relatively young geologic age of the mountain (Hemp 2006b; Hemp et al. 2015). The occurrence of the giant Entandrophragma adds another treasure to these valleys. However, past land use and ongoing illegal logging activities destroyed most of these unique habitats and perhaps even taller specimens of Entandrophragma. During our studies we surveyed the whole mountain. Only $7 \mathrm{~km}^{2}$ of potential habitat, i.e. submontane Newtonia forest are left in the biggest valleys, e.g. in Kikafu, Weru-Weru, Rau and Mrusunga valley, most of it already heavily impacted. If we extrapolate the number of 16 large trees $(>50 \mathrm{~m})$ per ha calculated on the base of our permanent plots, to the about 70 ha of still existing undisturbed Newtonia forest at the southern slope of Kilimanjaro, only approx. 1100 large individuals of E. excelsum may still exist. This demonstrates the long-lasting and overwhelming effect of humans on Kilimanjaro's natural vegetation, in particular on forests (Hemp 2006b) reflecting world-wide trends of losses in tree numbers (Crowther et al. 2015).

\section{Conclusion}

The inclusion of these valleys into the immediately neighboring Kilimanjaro National Park would be an excellent and urgent possibility of protection. Else Kilimanjaro will not only lose a precious biogeographical archive and a hotspot of biodiversity but also the tallest trees of Africa.

Acknowledgments This study was supported by the Deutsche Forschungsgemeinschaft (DFG) and the Swiss National Science Foundation (SNSF) in the context of DFG Research Unit FOR 1246. We thank COSTECH, TAWIRI and TANAPA for granting research permits. We thank two anonymous reviewers for their helpful comments.

Open Access This article is distributed under the terms of the Creative Commons Attribution 4.0 International License (http://creativecommons.org/licenses/by/4.0/), which permits unrestricted use, distribution, and reproduction in any medium, provided you give appropriate credit to the original author(s) and the source, provide a link to the Creative Commons license, and indicate if changes were made.

\section{References}

Anderson GD (1982) The soils and land use potential of the southern and eastern slopes of Kilimanjaro. IRA, Univ. Dar es Salaam, Tanzania

Ashton P (2014) On the forests of tropical Asia. Lest the memory fade. Kew, Surrey

Braun-Blanquet J (1964) Pflanzensoziologie. Wien

Crowther TW et al (2015) Mapping tree density at a global scale. Nature 525:201-205

Ensslin A, Rutten G, Pommer U, Zimmermann R, Hemp A, Fischer M (2015) Effects of elevation and land use on the biomass of trees, shrubs and herbs at Mount Kilimanjaro. Ecosphere 6(3):1-15

FTEA (1952-2012) Flora of Tropical East Africa. Royal Botanic Gardens Kew, London

FWTA (2014) Flora of West Tropical Africa. Royal Botanic Gardens Kew, London, eBook edition of Volumes 1-3 of original 2nd edition 
Grubb PJ (1977) Control of forest growth and distribution on wet tropical mountains: with special reference to mineral nutrition. Ann Rev Ecol Syst 8:83-107

Hemp A (2002) Ecology of the pteridophytes on the southern slopes of Mt. Kilimanjaro. Part I: Altitudinal distribution. Plant Ecol 159:211-239

Hemp A (2006a) Continuum or zonation? Altitudinal diversity patterns in the forests on Mt. Kilimanjaro. Plant Ecol 184(1):27-42

Hemp A (2006b) Vegetation of Kilimanjaro: hidden endemics and missing bamboo. Afr J Ecol 44:305-328

Hemp C, Kehl S, Schultz O, Wägele W, Hemp A (2015) Climatic fluctuations and topography as motor for speciation: case study on Parepistaurus Karsch, 1896 (Orthoptera: Acrididae, Coptacridinae). Syst Entomol 40(1):7-34. doi:10.1111/syen.12092

http://git-forestry-blog.blogspot.com/2008/07/tallest-tree-in-africa-is-you-guessed.html. Accessed 29 April 2016

Keith H, Mackey BG, Lindenmayer DB (2009) Re-evaluation of forest biomass carbon stocks and lessons from the world's most carbon-dense forests. PNAS 106:635-640

King DA (1991) The adaptive significance of tree height. Am Nat 135:809-828

Klein A (2016) Tallest known tropical tree discovered in Malaysia's lost world. New Sci. (https://www. newscientist.com/article/2092974-tallest-known-tropical-tree-discovered-in-malaysias-lost-world/)

Koch GW, Sillett SC, Jennings GM, Davis SD (2004) The limits of tree height. Nature 428:851-854

Larjavaara M (2014) The world's tallest trees grow in thermally similar climates. New Phytol 202:344-349

Larjavaara M, Muller-Landau HC (2010) Rethinking the value of high wood density. Funct Ecol 24:701-705

Laurance WF et al (2000) Rainforest fragmentation kills big trees. Nature 404:836

Lindenmayer DB, Laurance WF (2016) The unique challenges of conserving large old trees. TREE. doi:10. 1016/j.tree.2016.03.003

Lindenmayer DB et al (2012) Global Decline in large old trees. Science 338:1305

Lindenmayer DB et al (2014) New policies for old trees: averting a global crisis in a keystone ecological structure. Conserv Lett 7:61-69

Newman MF, Burgess PF, Whitmore TC (1999) Malesian dipterocarps. foresters' CD-ROM manual. RBGE, Edinburgh

Odner K (1971) A preliminary report on an archaeological survey on the slopes of Kilimanjaro. AZANIA 6:131-149

Parris BS (2002) New species and new combinations in African Grammitidaceae (Filicales). Kew Bull 57(2):428

Reyes G, Brown S, Lugo, AE (1992) Wood Densities of tropical tree species-General Technical Report S0-88. Forest Service Southern Forest Station, United States Department of Agriculture, New Orleans, Louisiana

Rossi S, Anfodillo T, Menardi R (2006) Trephor: a new tool for sampling microcores from tree stems. IAWA J 27:89-97

Rutten G, Ensslin A, Hemp A, Fischer M (2015) Vertical and horizontal vegetation structure across natural and modified habitat types on Mount Kilimanjaro. PLoS One 10:e0138822

Tng DYP, Williamson GJ, Jordan GJ, Bowman DMJ (2012) Giant eucalypts- globally unique fire-adapted rain-forest trees? New Phytol 196:1001-1014

Valentine HT, Makela A (2012) Modeling forest stand dynamics from optimal balances of carbon and nitrogen. New Phytol 194:961-971

Verdcourt B (2002) Adiantaceae. In: Beentje HJ, Ghazanafar SA (eds) Flora of Tropical East Africa. Royal Botanic Gardens, Kew, London

Verdcourt B (2007) A new species of Garcinia L. (Guttiferae), from Tanzania. Kew Bull 61(4):613-614

Wheeler EA (2011) InsideWood-A web resource for hardwood anatomy. IAWA J 32:199-211

Whitmore TC (1991) An introduction to tropical rain forest. Oxford University Press, Oxford

Williamson GB, Wiemann MC (2010) Measuring wood specific gravity correctly. Am J Bot 97:519-524

World Conservation Monitoring Centre (1998) Entandrophragma excelsum. The IUCN Red List of Threatened Species 1998: e.T33909A9818317. http://dx.doi.org/10.2305/IUCN.UK.1998.RLTS. T33909A9818317.en. Accessed 29 April 2016 